\title{
New methods applied to interpretations of pollen data in the Holocene - selected examples from the last decade
}

\author{
${ }^{*}$ Irena A. Pidek, **Anna Filbrandt-Czaja, ${ }^{* * *}$ Agnieszka M. Noryśkiewicz, \\ ****Bożena Noryśkiewicz, ${ }^{* * * * *}$ Satu Räsänen
}

\author{
*Department of Physical Geography and Palaeogeography, Institute of Earth Sciences, \\ Maria Curie-Skłodowska University, al. Kraśnicka 2 c/d, 20-718 Lublin, Poland \\ e-mail: i.pidek@poczta.umcs.lublin.pl \\ ** Laboratory of Ecological Processes Modelling, Institute of Ecology and Protection of Environment, \\ Nicolaus Copernicus University, Gagarina 9, 87-100 Toruń, Poland \\ e-mail: afczaja@umk.pl \\ *** Laboratory for Natural Environment Reconstruction, Institute of Archeology, \\ Nicolaus Copernicus University, Szosa Bydgoska 44/48, 87-100 Toruń, Poland \\ e-mail: anorys@umk.pl \\ ****Sedimentology and Palaeoecology Laboratory, Institute of Geography, \\ Nicolaus Copernicus University, Gagarina 9, 87-100 Toruń, Poland \\ e-mail: norys@umk.pl \\ ${ }^{* * * * *}$ Department of Geography, University of Oulu, PL 3000, 90014 Oulu, Finland \\ e-mail: satu.rasanen@oulu.fi
}

\begin{abstract}
The results of palynological analyses of the Holocene deposits and modern pollen deposition in Poland and Finland are used to illustrate the progress in pollen analysis - the main palaeoecological method. The increased potential of modern palaeoecology for reconstruction of vegetation and for drawing conclusions on other environmental variables (climate, water conditions, landscape, anthropogenic disturbances) is demonstrated. Pollen analysis - develops at present interpretive tools for precise reconstruction of the structure and composition of vegetation and climate conditions. The progress consists in the quantitative presentation of pollenvegetation-climate relationships based on the examination of modern pollen deposition. The application of numerical analyses to pollen data allows correlating pollen spectrum features with the landscape/vegetation type. Special attention is paid to the Holocene vegetation changes of the transitional zone between boreal forest and tundra in the areas subjected to weak anthropopression (e.g. Lapland), which reflect climatic changes. Databases of modern pollen analogues are based on analysis of samples of surface mosses and contents of Tauber traps. These traps are used in Poland in investigations conducted as a part of the Pollen Monitoring Programme (http://pmp.oulu.fi). The correlation of Tauber-trap data with aerobiological ones contributes to understanding of the relationship between pollen production and climate elements. Additionally, the precise $\mathrm{C}^{14}$ dating allows a near-annual resolution in fossil deposits to be obtained more frequently. Due to time scales comprising hundreds of years, pollen analysis can provide means to resolve questions inaccessible for direct observation.
\end{abstract}

Key words: pollen analysis, modern pollen deposition, pollen-vegetation relationship, pollen monitoring, Tauber traps. 


\section{Introduction}

Palaeoecology of the Quaternary and research on palaeoenvironment provide basic information for numerous investigations of modern ecosystems. Many processes important for understanding of composition and dynamics of vegetation and climate are active in long periods. Palaeoecology has means that allow analysing, to a larger and larger extent, phenomena inaccessible for scientific experiment or direct observation due to time scales comprising hundreds of years (Huntley 1996). During the last decade, we have observed an intensive development of interpretive tools, especially with respect to pollen analysis which still remains the main palaeoecological method. Pollen-based reconstructions of vegetation are carried out and conclusions on other environmental variables, such as climate, water conditions, soils, landscape, anthropogenic disturbances and the like, are drawn.

In late 1990s the number of annually laminated lake sediment investigated by multi-proxy approach increased (Ralska-Jasiewiczowa et al. 1998; Brauer et al. 1999; Goslar et al. 1999) which enabled precise correlation and synchronization of the Late Glacial varved lake sediments from Europe in comparison with Greenland Ice-core records (Litt et al. 2001). High resolution of such deposits enabled establishing the duration of Younger Dryas, the Elm decline in Europe and other important events in the Late Glacial and Holocene vegetation history (Latałowa 2003a). Non-pollen microfossils (fungal spores, algae, Cladocera remains) are also examined along with pollen analysis, thus adding precision to palaeoecological interpretations (van Geel 2006; Jankovska \& Komàrek 2000; Latałowa 2003b).

A variety of numerical methods were used to explore the multidimensional pollen data, and to relate pollen assemblages to environmental variables. Numerical techniques were applied to Holocene pollen sequences (Nalepka 2005; Berglund et al. 2008), to interpretation of modern pollen rain and the structure of phytocoenoses in which pollen samples were collected (Hrynowiecka-Czmielewska et al. 2007) and to assess modern pollen/land-use relationships in ancient cultural landscapes of north-western Poland (Makohonienko et al. 1998).

A team effort of Polish palynologists - new edition of isopollen maps - revealed the history of vegetation in Poland since Late Glacial through the whole Holocene to modern times (Ralska-Jasiewiczowa et al. (eds.) 2004).

In the last years considerable results in the field of palaeoecological modelling were achieved thanks to the activity of POLLANDCAL network (Gaillard et al. 2008). The development of theoretical models of pollen dispersal and the determination of the spatial scale of the landscapes represented by pollen was demonstrated among others by Sugita (1994, 1998), Davis (2000), Bunting (2003), Bunting

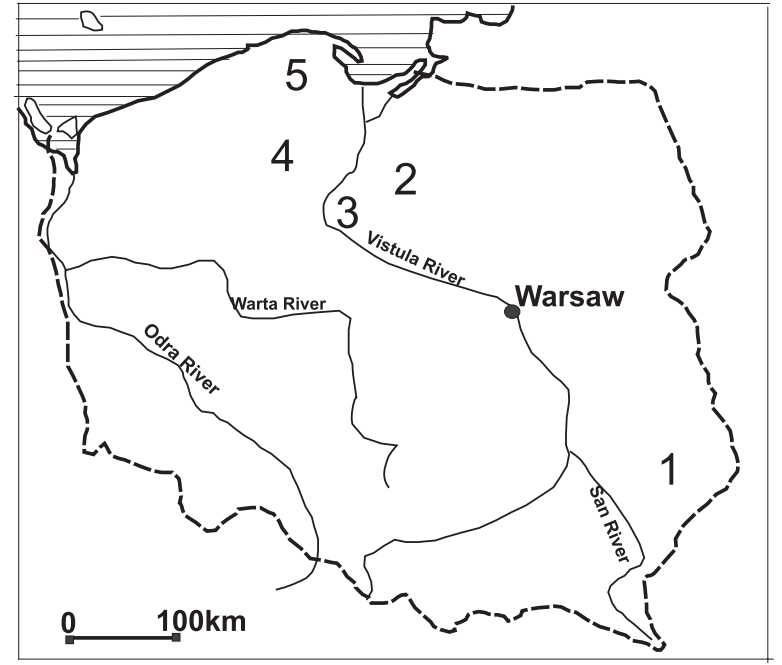

Figure 1. Regions in Poland where pollen monitoring according to PMP rules has been in progress: 1 - Middle Roztocze, 2 - Brodnica Lakeland, 3 - Torun Basin, 4 - Tuchola Forests (Wierzchlas Reserve and Zaborski Landscape Park), 5 - Kashubian Lakeland and Trójmiejski Landscape Park

et al. (2004). However estimating annual pollen production of a given taxon and source areas of pollen need further studies especially in moderate zone where these data are quite scarce. Rough pollen productivity estimates (PPEs) have already been obtained for northern Europe (Broström 2002, Broström et al. 2008; Räsänen et al. 2007a) and Switzerland (Mazier et al. 2008; Sjögren et al. 2008), but still lacking are PPEs from Eastern Europe.

The need for quantification pollen production, deposition and source areas caused a considerable increase of research on modern pollen deposition since 1990s. These investigations comprise analysis of surface moss samples (Gaillard et al. 1994; Emanuelson et al. 1998; Räsänen 2001), the uppermost part of lake deposits (Wilmshurst et al. 2005) and pollen monitoring with the use of Tauber traps (Hicks 2001, 2007; van der Knaap et al. 2001; Tonkov et al. 2001)

Standardised methods used in the Pollen Monitoring Programme (PMP) enabled determination of annual pollen accumulation rates (PARs; pollen grains $\mathrm{cm}^{-2}$ year $^{-1}$ of a given taxon). This international project aims at quantifying modern pollen deposition of tree, shrub and herb species in different vegetation units with the aid of Tauber pollen traps (Hicks \& Hyvärinen 1986). According to PMP guidelines (Hicks et al. 1996, 1999), monitoring of pollen dispersal and deposition is currently carried out in many European regions and outside Europe covering different vegetation types and landscapes (http://pmp.oulu.fi/). 
Tauber-type pollen traps have been placed in Poland since 1998. Nowadays, the monitoring in our country is conducted in five different regions (Fig. 1): the Middle Roztocze (9 traps), the Brodnica Lakeland (3 traps), the Torun Basin (3 traps), the Tuchola Forests ( 7 traps), the Kashubian Lakeland (6 traps), Trójmiejski Landscape Park (4 traps). They are a part of a longer N-S European transect.

Until now these investigations have concentrated on assessing pollen accumulation rates in moderate zone (Filbrandt-Czaja et al. 2003), pollen-vegetation relationship (Pidek 2007), presence/absence threshold values of pine and spruce in the vegetation based on annual pollen deposition (Pidek et al. 2008) and estimating spatial scale of pollen dispersal (Poska \& Pidek 2007). Possibilities of interpretation increase when annual pollen sums from Tauber traps are compared with the results of aerobiological monitoring with the use of volumetric samplers (Levetin et al. 2000; Pidek et al. 2006; Święta-Musznicka \& Zimny 2007).

This paper is a brief review and is aimed at presenting some recent developments in pollen analysis. Based on several examples taken from the authors' own investigations and taking into account relevant papers published in the last decade, there are discussed some new methods used in pollen studies of the Quaternary, which contribute to a more precise interpretation of fossil pollen diagrams. The objective of this paper is to define what the progress has taken place in palynology in the last decade and to present the contribution to both palaeoecology and ecology.

\section{Review of recent developments in palynology}

\subsection{Refined interpretation of traditional pollen diagrams by the use of modern pollen deposition estimations}

The traditional percentage pollen diagram still remains the most common form of presentation of the results of palynological analyses, but its interpretation is more precise due to the use of the results of examination of modern pollen deposition.

The site at Wierzchlas is an example of such studies. At this site there were examined four fossil profiles (two from Lake Mukrz and two from the surrounding peatbogs - Fig. 1), 33 surface samples, and the material from three Tauber traps situated near the site (Noryśkiewicz A. M. 2001). The obtained results allow examining the changes in vegetation cover which have occurred in the study area from the end of the last glaciation to the present time (i.e. during the period of about $14 \mathrm{ka}$ ).

All profiles are considerably similar, as far as the pattern of percentage curves of almost all pollen components

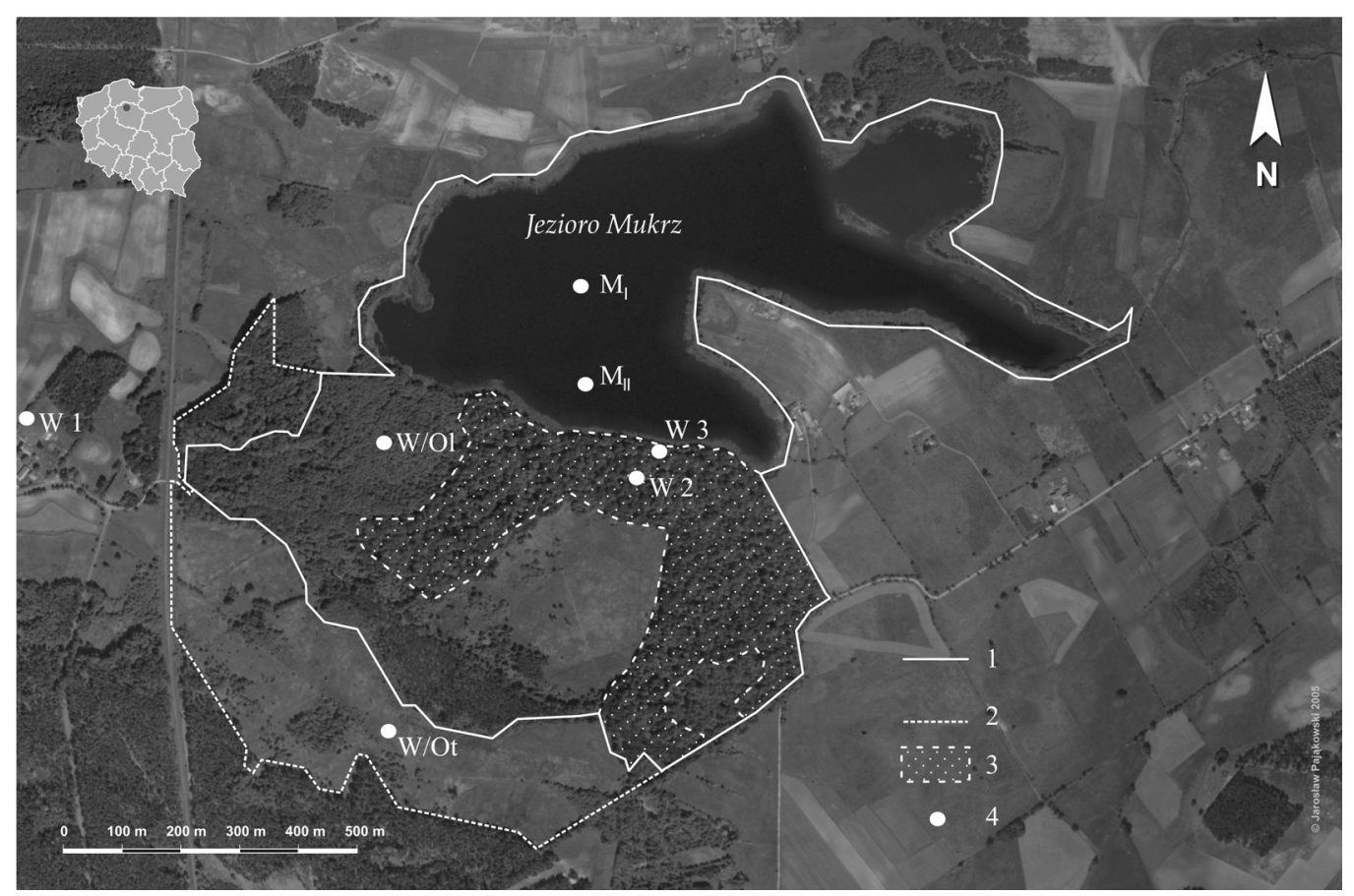

Figure 2. Location of pollen traps and corings near the Mukrz Lake: 1 - border of the reserve, 2 - border of the buffer zone, 3 forest with yew, 4 - location of the palinological profiles $\mathrm{M}_{\mathrm{I}}, \mathrm{M}_{\mathrm{II}}, \mathrm{W} / \mathrm{Ol}$, W/Ot and traps W1, W2, W3 (after Pająkowski 2005; Noryśkiewicz 2001, 2006) 


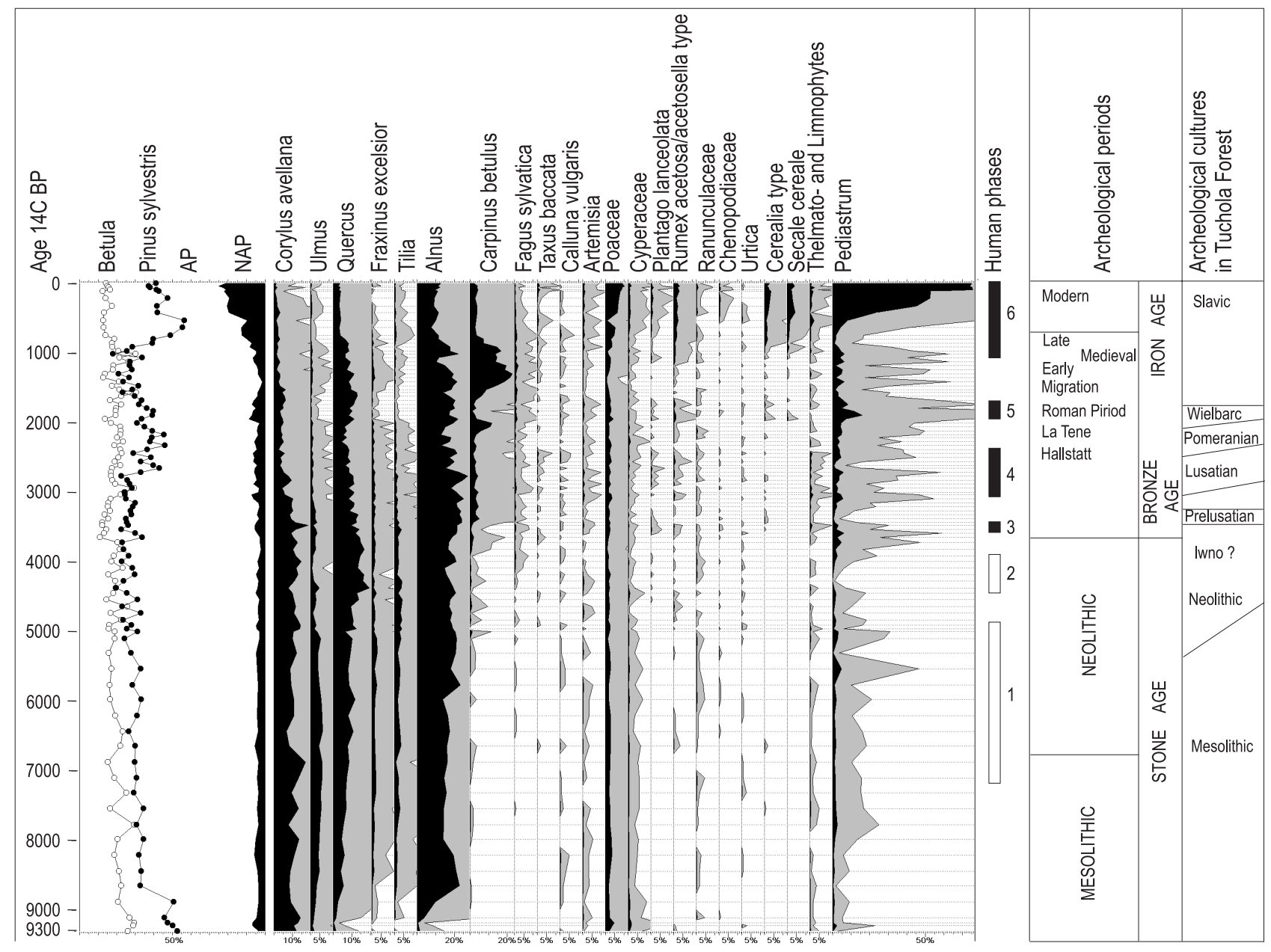

Figure 3. Simplified percentage pollen diagram from Wierzchlas site

is concerned. Thus, it was possible to make the reconstruction of continuous succession of vegetation cover, both regional and local, in the area of the present yew reserve, from the turn of the Oldest Dryas and Bölling, through the whole Holocene, to the present time (Fig. 2). Regional pollen succession in the examined profiles represent the late glacial and the complete Holocene vegetation succession.

The investigations conducted near Wierzchlas also provide new important information about the history of yew. Taxus baccata in the environs of Lake Mukrz was the component of forest already since the Subboreal period. Its encroachment in this area was connected with the beginning of hornbeam and beech spread. The studies on the modern distribution of yew pollen grains in Wierzchlas (Noryśkiewicz A. M. 2001, 2006) indicate that even its low values in the diagram result from the occurrence of yew trees in contemporary forests, but it is not possible to estimate its quantitative proportion in tree stands. The results of pollen analysis of surface samples from the forest litter and lake bottom as well as measurements of annual pollen deposition reveal that, in the conditions prevailing in Wierzchlas (large tree stocking), yew pollen grains can hardly migrate beyond the area of mass occurrence of yew in forest (Noryśkiewicz A. M. 2001). Monitoring pollen deposition into Tauber traps according to Pollen Monitoring Programme rules has been conducted in the Wierzchlas yew reserve since 1998. Figure 3 illustrates the values of Taxus, Alnus, Betula and Pinus pollen grains recorded in particular years at two sites (situated $0.5 \mathrm{~km}$ apart) - in forest opening and in open vegetation both in terms of percentages and annual deposition per $\mathrm{cm}^{2}$ (pollen accumulation rates PARs). Percentage pollen values were calculated according to arborum pollen sum (AP) set to $100 \%$. Twice, due to destruction of the Tauber trap, there were no data available from the forest (in 2000 and 2007). The amount of yew pollen is presented on the background of alder, pine and birch pollen deposited per a unit area (Fig. 4). In comparison to other trees, presence of yew pollen is very 


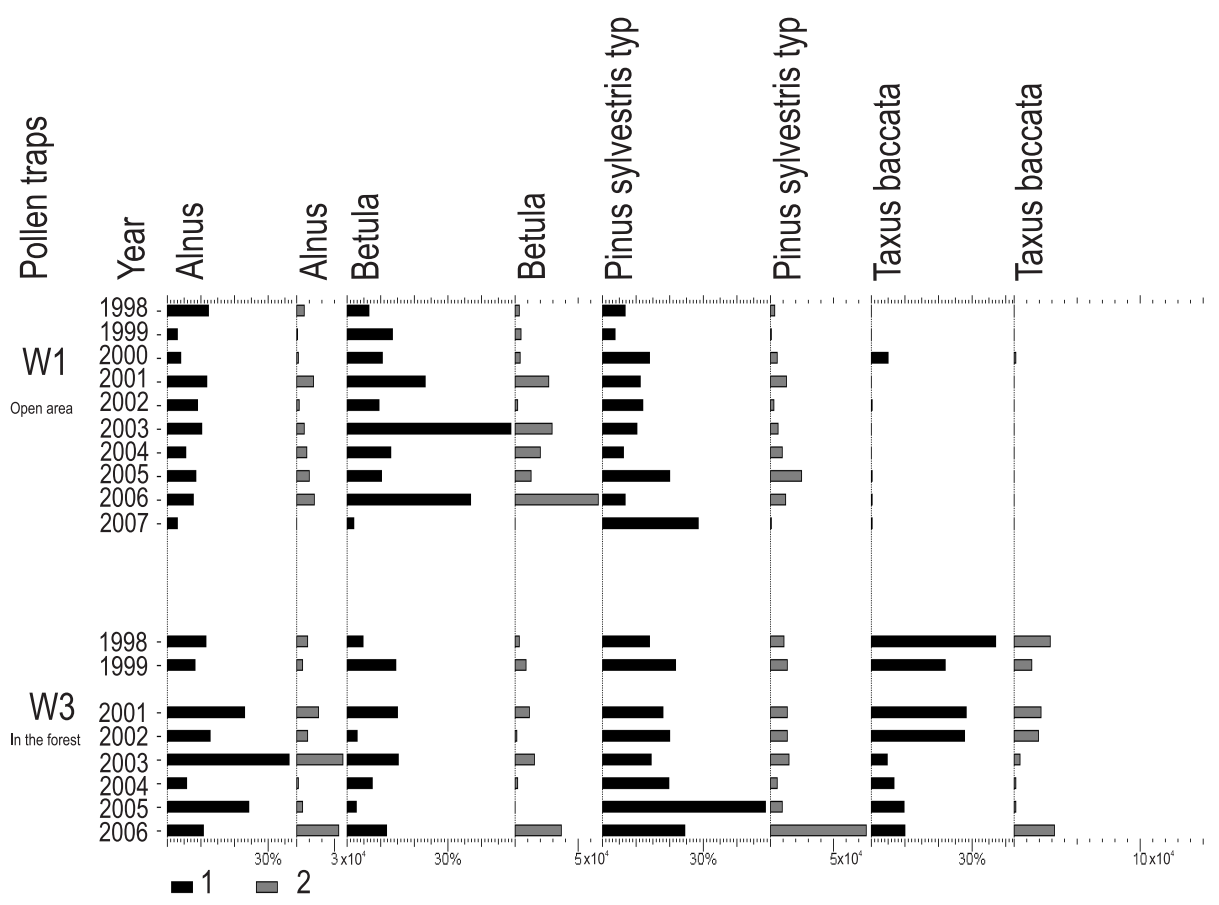

Figure 4. Percentages versus pollen accumulation rates (PARs) of Taxus, Alnus, Betula, Pinus in the Wierzchlas reserve and in its surroundings (open vegetation)in pollen traps; 1 - percentage values, 2 - influx values

poorly marked in open area and achieves higher values of deposition only in a peak year 2000 .

Detailed palaeoecological interpretation of the pollen diagram and the results from surface samples allow many times the hypotheses concerning the problem of potential natural vegetation in the examined area to be verified. The results of pollen analysis of the bottom deposits in Lake Mukrz exclude the existence of typical Pomeranian beech woods in the examined area in the past. The pollen percentages of beech (Fagus sylvatica) at the Wierzchlas site do not exceed 2\% (Noryśkiewicz A. M. 2001), indicating that beech occurred only as an admixture in deciduous forests. Single individuals of beech growing near Wierzchlas show the pollen signal in surface samples as the Fagus pollen percentages not exceeding $0.5 \%$ of AP. Therefore, the theory that the modern forest community in the reserve is a beech wood anthropogenically transformed by beech cutting (Myczkowski 1961) has not been confirmed by palynological analyses (Noryśkiewicz A. M. 2006). It was probably deciduous forest with yew, of the modern Tilio-Carpinetum dry-ground forest type.

\subsection{Numerical analyses as interpretive tools for estimation of human disturbances in vegetation cover}

Presence of anthropogenic indicators in pollen diagrams reveals human impact on natural vegetation cover and landscape near archaeological sites. In the diagram from Wierzchlas, six settlement phases were distinguished, which were associated with increased human activities (Fig. 3). Pollen analysis indicates that the anthropogenic influence on the natural environment near Wierzchlas was weak till the Bronze Age, similarly as in the other parts of the Tuchola Forests. It was associated with the fact that in the Neolithic period the Mesolithic type of economy, i.e. hunting, gathering and fishing, persisted in the area in question. The significant influence of man on the environment is reflected in pollen diagrams only from the Bronze Age and it was associated with the development of the Iwieńska culture when the economy was already based also on breeding, in addition to the earlier types. Agriculture became more important as late as the period of Roman influences. These changes are marked very well in percentage values of trees of dry-ground forests such as Carpinus, Quercus, Tilia. 


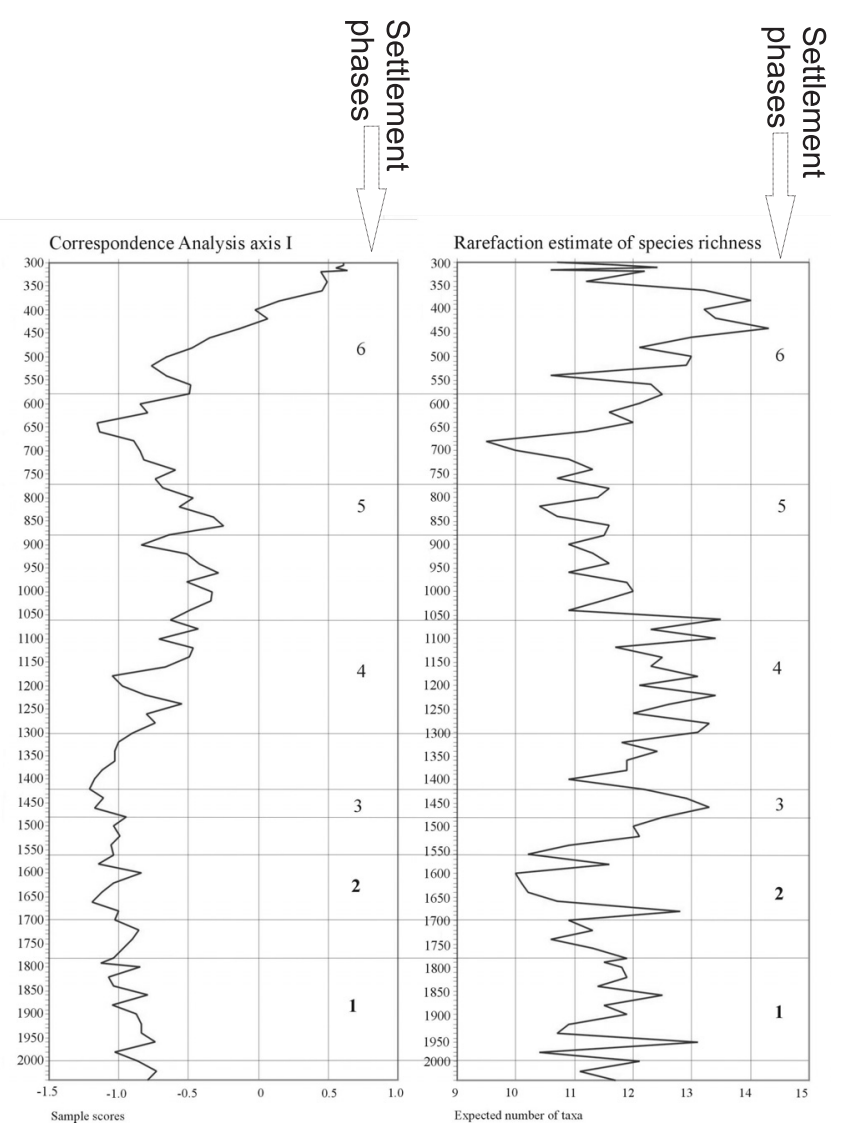

Figure 5. Stratigraphical plot of sample scores on the first CA axis (left) and rarefaction estimate of richness $(\mathrm{E}(\mathrm{Sn}))$ (right) for Wierzchlas

From the middle of the Early Middle Ages, the destructive influence of man on the natural environment constantly increased. This is visible in rising pollen curves of Cerealia, Secale, Rumex acetosa/acetosella, Plantago lanceolata (Fig. 3) and is also confirmed by the results of numerical analyses. Correspondence analysis (CA) from the CANOCO 4.5 package (ter Braak \& Šmilauer 2002) and rarefaction analysis included in the POLPAL programme (Walanus \& Nalepka 1999) were used. CA was selected for ordering the samples, because it is a perfect technique for analysing changes of vegetation based on palynological data. It concentrates on the shapes of curves and maximizes the relationship between samples and taxa along the first ordination axis illustrating the gradient of human influence on the environment at the investigated site. The analysed samples are situated along the first ordination axis in stratigraphic order (Jacobson \& Grimm 1986). In correspondence analysis, the bottom pollen spectra were not included, as they do not reveal human influence. Sporadically occurring taxa, which reached the minimum percentages, were also left out.
Rarefaction analysis was used to calculate the expected number of taxa, i.e. $\mathrm{E}(\mathrm{Sn})$ - the rarefaction index of species abundance. It allows calculating species diversity in samples of different sizes, which is a typical feature of pollen spectra (Tipper 1979). The results of rarefaction analysis are also presented as the curve drawn along the depth scale, i.e. in stratigraphic order. In this analysis, the same palynological spectra were taken into account as were used in CA, but all taxa identified in the pollen analysis were considered. The ordination plot of correspondence analysis (Fig. 5) indicates that the influence of Neolithic settlement on the environment was the weakest (settlement phases 1 and 2) in comparison with the other settlement periods in the examined area. The results of rarefaction analysis (Fig. 5) show that human activity caused the increase of species abundance resulting from anthropogenic disturbances of landscape.

A great similarity between the curve marked by sample indicators along the first axis of CA and the rarefaction curve indicates that both vegetation changes and species abundance changes were associated with the effect of the same factor - human influence. The use of numerical methods for the analysis of palynological data expands interpretive possibilities of pollen analysis.

Based on pollen and numerical analyses (Fig. 3 and 5), it was found that the intensity of the Neolithic settlement, and in consequence the vegetation cover change, was the weakest among all the distinguished settlement phases. More intensive anthropopression on vegetation communities began only in the Bronze Age, as is illustrated by the curve shape (Fig. 5).

\subsection{Advances in developing highly-resolved palynological records}

The improvements of radiocarbon dating methods (i.e. the increasingly common use of accelerator mass spectrometry AMS) as well as the use of modern techniques in order to obtain near-annual resolution in deposits allow a more and more precise placing of vegetation changes on the time scale. An example are fine-temporal resolution studies conducted using a technique which allows to obtain contiguous $1 \mathrm{~mm}$ thick slices of peat, each of which should typically represent 2-5 years - an example from Finnish Lapland (Räsänen et al. 2007b)

The peat monolith was collected from a small (ca. $50 \times 200 \mathrm{~m}$ ) mire from the vicinity of a large tourist resort, Saariselkä, in Finnish Lapland. The aim of the research was to study the changes in pollen spectra reflecting the increasing human impact on vegetation during the 20th century (Fig. 6) in the area with weak anthropopression.

The peat monolith $(4 \times 4 \times 60 \mathrm{~cm})$ was frozen and 100 contiguous slices of $2-4 \mathrm{~mm}$ in thickness were cut in order to obtain near-annual temporal resolution. The pro- 
file was dated with 15 AMS dates, which provides a robust age-depth model enabling the calculation of pollen accumulation rates (PARs) when the exact volume of the sample and the density of added marker grains (Lycopodium spores) are known.

The pollen histogram reveals that Pinus density increased remarkably during the second half of the 20th century, which may be a consequence of increasing biomass (the altitudinal tree line moved upwards the nearby fjell). At the same time, the amount of Betula pollen decreased, which is probably due to growing numbers of reindeer grazing in the area. This evidence is supported by the increasing amount of coprophilous fungal spores: the statistics of reindeer herds tell that the number of reindeer is 4 -fold higher in the 1980s than it was 20 years earlier, and this is reflected in the appearance of fungal spores.

The changes in pollen taxa reflecting human interference (Poaceae, Ranunculus, Rumex etc. = taxa of disturbed sites) are very subtle compared to the intensity of the clearance of trees from e.g. slalom slopes, which are sown with grass seeds. The small amount of these pollen taxa is probably due to the small basin size and thick forest preventing the pollen of low herbaceous plants reaching it.

\subsection{Pollen deposition measured}

by Tauber traps against aerobiological monitoring by volumetric samplers

Data sets from pollen monitoring based on Tauber traps can be successfully correlated with aerobiological ones, i.e. measurements made by using volumetric samplers. Both data types, together with climatic factors (air temperature, precipitation, wind speed and direction), contribute to finding the relationship between the volume of pollen production and deposition and meteorological parameters, as well as the ability of different taxa pollen to be transported for long distances (Levetin et al. 2000; Ranta et al. 2007).

However annual pollen deposition into Tauber traps (grains $\mathrm{cm}^{-2}$ ) and airborne pollen concentration measured by Burkard or Lanzoni volumetric samplers (grains in $1 \mathrm{~m}^{3}$ of air) can not be compared directly. In order to make a correlation of Betula pollen deposited into Tauber traps in the Roztocze and volumetric Lanzoni sampler in Lublin in the period 2001-2007, the percentage pollen index (PI) was calculated from the data obtained by means of the two methods (Pidek et al. 2008b). The PI was calculated according to the following formula:

$\mathrm{PI}=$ (annual birch pollen sum in a given year / total sum of birch pollen grains in the period 20010-2007) x $100 \%$

The results are presented in Table 1.

Table 1 shows that in both areas the obtained values of PI were very similar. The highest values (peak years of birch pollen) both in terms of annual pollen sum and PI were obtained in 2003 and 2006. Independently of the used method, the amount of recorded birch pollen revealed similar trend in Lublin and in the Roztocze region in spite of $120 \mathrm{~km}$ distance between pollen monitoring sites and differences in vegetation cover (Pidek et al. 2008).

Table 1. Annual pollen sums of Betula in Roztocze (measured by Tauber traps) and in Lublin (Lanzoni volumetric sampler) in the period 2001-2007 [acc. to Pidek et al. 2008b, modified]

\begin{tabular}{|c|c|c|c|c|}
\hline \multirow{2}{*}{ Year } & \multicolumn{2}{|c|}{ Roztocze } & \multicolumn{2}{c|}{ Lublin } \\
\cline { 2 - 5 } & $\begin{array}{r}\text { average annual pollen sum per } \mathrm{cm}^{2} \\
\text { and percentage pollen index (PI) }\end{array}$ & \multicolumn{2}{c|}{$\begin{array}{r}\text { average annual pollen sum in } \mathrm{m}^{3} \text { of air } \\
\text { and percentage pollen index (PI) }\end{array}$} \\
\hline \multirow{2}{*}{2001} & Annual sum & PI [\%] & Annual sum & PI [\%] \\
\hline 2002 & 2458 & 14.5 & 13670 & 12.1 \\
\hline 2003 & 13845 & 4.7 & 5354 & 4.7 \\
\hline 2004 & 3217 & 27.0 & 34134 & 30.2 \\
\hline 2005 & 7932 & 6.3 & 12647 & 11.2 \\
\hline 2006 & 9701 & 15.5 & 6951 & 6.1 \\
\hline 2007 & 6762 & 18.9 & 22899 & 15.4 \\
\hline Total & 51333 & 13.2 & 17410 & 100 \\
\hline
\end{tabular}




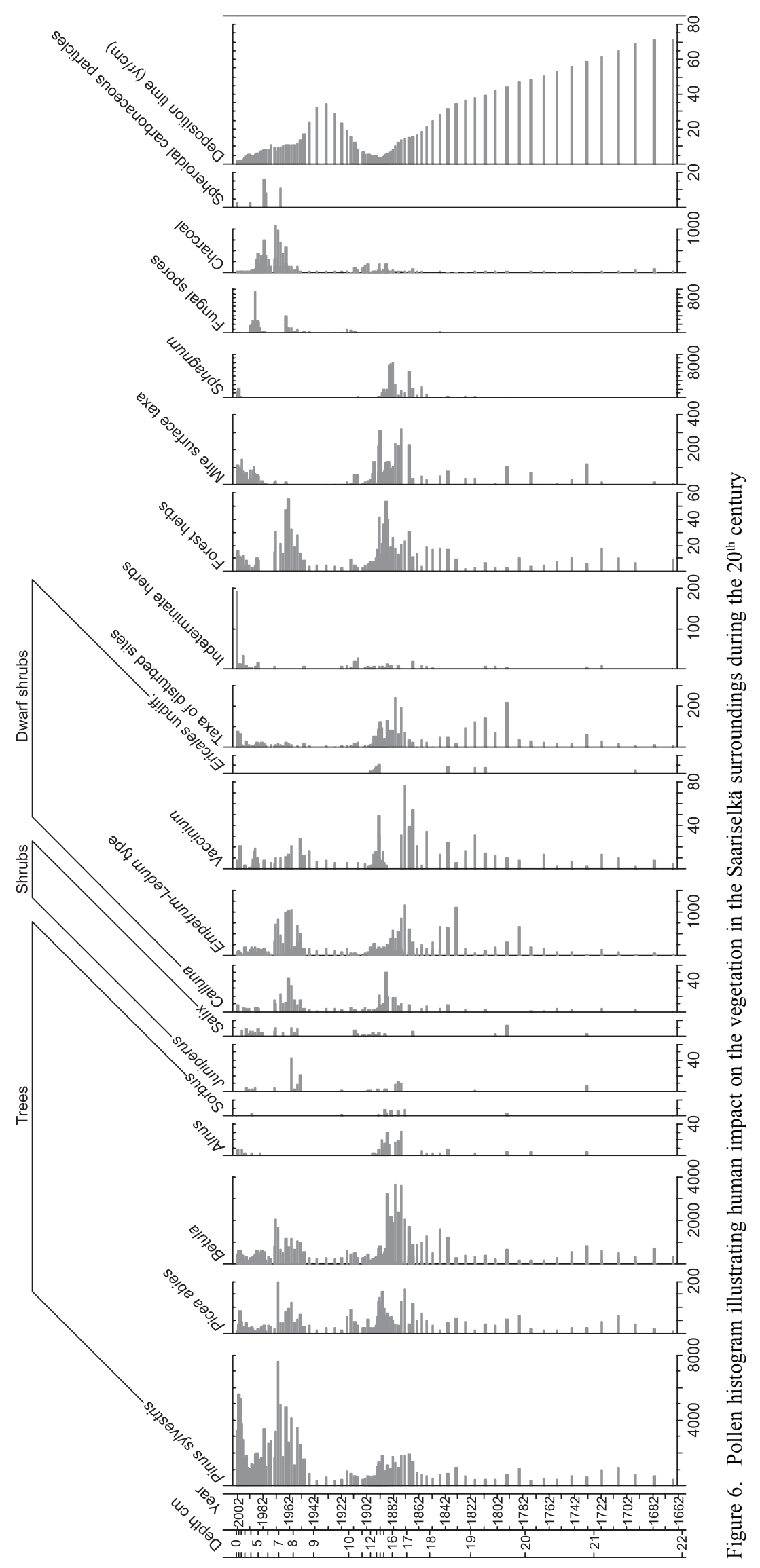




\subsection{Climate controlled occurrence of peak years in pollen production and deposition of alder}

Alnus belongs to trees producing large quantities of pollen causing allergic reactions so is in the range of interest not only of botanists and aerobiologists, but also allergologists. Due to cross reactions to alder and birch pollen, researchers undertake analyses of alder pollen concentrations, pollen season patterns and related meteorological factors (Gioulekas et al. 2004; Kasprzyk et al. 2004).

Ten-years pollen data series of alder (1998-2007) collected in Roztocze in frame of the Pollen Monitoring Programme shows that annual pollen sums ranged between 5374 (in 1998) and 225 grains $/ \mathrm{cm}^{2}$ of area (in 2000) in the period under investigation (Tab. 2). Years of very abundant pollen deposition $(1998,2003,2006)$ and a very weak deposition $(2000,2005)$ were observed.

Based on the 10 years results of alder pollen deposition monitored in the Roztocze, there was investigated the influence of two climatic factors on the occurrence of peak pollen deposition years (Kaszewski et al. 2008). Spearman's rank correlation coefficient (Łomnicki 1995) was used to evaluate the effect of air temperature and precipitation on the abundance of Alnus pollen in Tauber traps in particular years. The analysis showed that the correlation coefficient values were statistically significant (negative correlation) for precipitation in August in the year preceding pollen emission and in February of the year of pollen emission, which suggests the influence of draught on alder pollen production. The Spearman's rank correlation coefficient between the annual Alnus pollen sum and mean temperature of June, July and August in the year preceding pollen emission showed no statistically significant values (Kaszewski et al. 2008).

\section{Discussion}

The presented examples do not include all methods used in modern pollen analysis. They indicate only some of the trends of its development towards better understanding pollen-vegetation-climate relationship. Detailed recognition of pollen dispersal and deposition in comparison to the well described vegetation composition and structure provides palynologists with suitable knowledge for interpretation of fossil pollen spectra. Different pollen trapping media - moss polsters and Tauber traps have particular significance for obtaining modern pollen analogues of previous environments. Moss polster studies were used to construct databases of pollen analogues typical of various communities in different climatic zones. In the last decade the potential of such database was proved in quantitative climatic reconstructions, among others by Cheddadi et
Table 2. Annual pollen sums of Alnus in Roztocze in the period 1998-2007

\begin{tabular}{|c|c|}
\hline Year & Annual Alnus pollen sum $\mathrm{cm}^{-2}$ \\
\hline 1998 & 5374 \\
\hline 1999 & 661 \\
\hline 2000 & 225 \\
\hline 2001 & 2836 \\
\hline 2002 & 1247 \\
\hline 2003 & 2015 \\
\hline 2004 & 1051 \\
\hline 2005 & 568 \\
\hline 2006 & 2950 \\
\hline 2007 & 861 \\
\hline
\end{tabular}

al. (1998), Peyron et al. (1998), Tarasov et al. (1999) and Whitmore et al. (2005).

Some conclusions resulting from the application of modern pollen spectra investigations to interpretation of fossil pollen diagrams are presented using the example of the Wierzchlas site (Noryśkiewicz A. M. 2006). Hicks \& Sunnari (2005) made a step further towards assessing the spatial precision of vegetation reconstructions by applying two techniques to pollen diagram from a small lake, Kutulahdenlampi, in northern Finland. One of these techniques is the use of pollen accumulation rates (PARs) and threshold values of presence/absence of individual taxa based on these. As a reference material they used long term average pollen deposition values monitored by a network of pollen traps. The other technique was the estimation of the relevant source area of pollen (RSAP) as developed by Sugita (1994). Hicks \& Sunnari (2005) paid special attention to the arrival of spruce because transitional zone between boreal forest and tundra is a sensitive indicator of climatic changes. The presence/absence threshold values for pine, spruce and birch - the main trees of this zone are of special importance and the determination of their threshold values improved in comparison to first rough estimates (Hicks 2001) when more sites and longer sample periods were taken into account (Hicks \& Sunnari 2005). The equally sensitive indicator of climatic changes is the variability of the forest limit in mountains. Based on precisely dated deposit cores from two small mires near the forest limit in the northern and central Swiss Alps, van der Knaap \& van Leeuwen (2002) located in time and examined vegetation changes, and also deduced the climatepollen relationship from the beginning of the $20^{\text {th }}$ century (1901-1996). 
In Poland Picea also belongs to taxa which are especially interesting from a point of view of palaeoecological interpretation, particularly because of the occurrence of the Middle Polish gap in spruce distribution. For the reconstruction of the Holocene history of spruce migration, different percentage pollen values are accepted as threshold values of spruce presence in forests (Obidowicz et al. 2004). Latałowa and van der Knaap (2006) assumed that $2 \%$ threshold tracks the advance of main spruce front during its Late Quaternary expansion in Europe.

In order to assess annual pollen accumulation rates for Picea in Poland, average values of spruce pollen deposition were calculated along the NW-SE transect of Tauber traps in Poland, which covers different types of vegetation from pine dominated forests through beech woods with small admixture of pine and mixed forests with spruce plantations to open situations. This allowed formulating preliminary conclusions concerning the threshold value for the presence of Picea in forest communities, both in terms of pollen accumulation rates (PARs) and percentages. Based on 10-year data series, it seems that over 60 pollen grains of Picea $/ \mathrm{cm}^{2} /$ year means the regional presence of scattered spruce trees in the surrounding vegetation. In terms of percentages, it is ca. $0.5 \%$ (Pidek et al. 2008a).

The results of examination of modern spruce pollen deposition were used for interpretation of fossil pollen spectra obtained from the bottom deposits of Lake Strażym in the Chełmno district (Central Poland). At present spruce reaches its northern distribution limit in this part of Poland. In the bottom sediments of Lake Strażym, spruce shows its maximum occurrence in the Atlantic period (0.6-0.8\%). Small amounts of Picea pollen grains throughout the profile (like in pollen traps) may indicate that the Brodnica Lakeland lay outside the close range of the genus (Noryśkiewicz B. 2005). However, it seems that this amount reflects presence of spruce within the local forest stands and needs further investigation with application of pollen accumulation rates.

The potential of modern palynological tools to reveal non-agricultural human impact on vegetation in northern boreal forest was presented in Figure 6. More case studies dealing with human impact problem can be found in warmer climate zones where the influence of man's economy on landscape was much more expressed. One of them is the high-resolution climate-pollen record for the last three thousands of years in the NW part of the Iberian Peninsula (Desprat et al. 2003). The age-depth model from the Vir-18 core was based not only on two ${ }^{14} \mathrm{C}$ dates, but also three historically dated botanical events in Galicia, i.e. the expansion of Juglans \& Pinus and the introduction of Eucalyptus. The pollen diagram revealed a two-step reduction of open deciduous oak forest since 975 cal BC which suggests climate as the main cause rather than socio-economic changes documented in historical archives. The Little Ice
Age was very well marked by low values of pollen accumulation rates between 1400 and 1860 cal AD, with a cold maximum about 1700 cal AD (Desprat et al. 2003).

In the last decade numerical approach to palynological data developed and different methods were applied to interpretation of pollen diagrams. The potential of use of correspondence analysis (CA) and rarefaction analysis for determination of human impact on vegetation during settlement phases is illustrated in Figure 5 and was shown among others by Filbrandt-Czaja and Piernik (2006). Nalepka (2005) proved that application of sample similarity matrix (SSM) analysis can indicate the most similar spectra and groups of the most similar spectra in two data tables, thereby identifying their possible correlation. Then the correlation (by the MultiCorr application) can indicate the most similar single spectra in several compared profiles. The results of numerical analysis helped to support the division of the pollen diagram into local pollen assemblage zones and to identification of cultural phases in the diagram (Nalepka 2005). Canonical variates analysis (CVA), used by Räsänen (2001), illustrated how the whole range of ecosystems, from treeless tundra via pure mountain birch forest and mixed (birch + pine) forest to pine forest are represented and distinguishable within the set of 58 moss polsters.

Nowadays, based on pollen data, it is possible not only to examine vegetation succession and to distinguish phases of intensive human activity (in fossil deposits), but to reconstruct the land use type, as well. Pastures can be distinguished from hay-growing meadows that were rarely grazed based on pollen analogues determined for modern pastures and meadows (Hjelle 1998; Emanuelson et al. 1998). Modern deposition of local pollen in vegetation/landscape types influenced by anthropopression is examined by the determination of the relationship between weeds of arable land and their pollen representation. The classic study by Behre (1981) with the list of anthropogenic indicators in pollen diagrams typical of arable land, ruderal habitats and pastures in northern and central Europe (among others, Cerealia, Centaurea cyanus, Fallopia, Polygonum aviculare types and others) is accompanied by new publications concerning southern Europe (Brun et al. 2007), in which to classical pollen indicators of arable areas some other have been added, which seem to be present rather in more southern countries (Papaver rhoeas-Group, Sinapis, Kickxia, Scleranthus, Euphorbia and Valerianella).

Besides pollen grains, also non-pollen microfossils were used for estimation of anthropogenic changes in landscape. The significance of analysis of coprophilous fungal spores for estimation of grazing intensity was illustrated using the example of the diagram from Saariselkä (Fig. 6). Coprophilous fungal spores provided additional information on the amount of grazing animals in the area under investigation, and helped to reveal human impact from pal- 
ynological samples with little additional work (Räsänen et al. 2007b). Their common occurrence and possibility of identification (van Geel et al. 2003; van Geel 2006) allow research to be conducted even in geographically distant areas like the Swiss Alps, Bhutan and the Azores (van Leeuwen 2007).

Since the work of Sugita (1994) modelling approach to pollen data has been pushed forward and resulted in development of the landscape reconstruction algorithm, a research strategy that combines modelling and a simulation approach in order to reconstruct vegetation quantitatively at both local and regional spatial scales using pollen data from small and large basins (Sugita 2007a, b). These models have been validated and tested within the activities of POLLANDCAL (POLlen LANDscape CALibration programme by Prof. Marie Jose Gaillard), which is a research network supported financially by NordForsk in the years 2001-2005 and still active (http://www.ecrc.ucl.ac.uk/pollandcal). The long term aim of the network was to achieve callibration tool for quantitative reconstruction of past landscapes using fossil pollen assemblages and had two major foci: (1) the collection of empirical data on modern pollenvegetation relationship and (2) the use and development of models and computer software (Gaillard et al. 2008). At present two models are available, Regional Estimates of Vegetation Abundance from Large Sites (REVEALS) and LOcal Vegetation Estimates (LOVE). REVEALS was validated and tested in southern Sweden (among others Hellman et al. 2008). The validation of LOVE, as well as applications of REVEALS and LOVE in various parts of Europe are under progress (Gaillard et al. 2008).

Correlation of results of different pollen monitoring methods can add precision not only to pollen productivity estimates but to determination of long-distance component in pollen spectra as well. Table 1 illustrates how birch pollen monitoring data in Lublin and in the Roztocze region recorded similar trends in pollen production. Spieksma et al. (2003) pointed out that intensified pollen production in some years can be favoured by weather conditions, and by the features associated with biology of tree development. In case of Betula biannual rhythm is considered i.e. alternating production of large assimilation surface of leaves and high number of inflorescences in successive years (Dahl \& Strandhede 1996). Modern pollen data from Wierzchlas (Fig. 4) and from the Roztocze (Tab. 1) seem to confirm that this rhythm can be traced in longer series but sometimes it is interrupted by two years of low birch pollen production following the peak year (Pidek et al. 2008b).

However occurrence of peak years over vast areas indicates the importance of climate factors, which influence pollen production (Latałowa et al. 2002; Pidek \& Kaszewski 2005). In the present paper, the analysis of weather elements potentially affecting alder pollen production and dispersal has shown that in the case of the Roztocze region, where 10-year pollen data series is available, precipitation levels in August of the year preceding Alnus pollen emission and in February in the year of pollen emission are of essential significance (Kaszewski et al. 2008).

Climate-pollen relationship has been investigated most frequently in areas where tree species are close to the limits of their distribution, because in such situations responses to changes are sensitively recorded. Autio and Hicks (2005) pointed out that the main factor which determines the amount of pollen that a tree produces in the northern regions is air temperature. Annual variation in meteorological parameters and pollen deposition monitored by Tauber traps in northern Finland showed that the quantity of pollen deposited is affected by July mean temperature, July effective temperature sum and total effective temperature sum for the year previous to pollen emission (Autio $\&$ Hicks 2005). The authors conclude that if the same annual pollen record can be extracted from the sediment, the pollen record can potentially provide a proxy for summer air temperatures.

The great similarity of the results obtained by two methods of pollen monitoring - using volumetric samplers and Tauber traps - allows a broader use of long series of pollen data not only for the interpretation of past climaticvegetation conditions, but also for forecasting future vegetation changes resulting from climate warming (Emberlin et al. 1997; Spieksma et al. 2003).

Last but not the least, palaeoecology uses genetics more and more frequently (Petit et al. 2003). Past colonization routes and locations of refugia can be inferred from variation in mitochondrial DNA in material collected from different populations of a particular tree species located within southern parts of Europe and immediately adjacent to the continent. Based on genetic data, the existence of some isolated populations of Pinus sylvestris in the Iberian and Italian Peninsulas during the last glacial maximum (LGM) was traced (Sinclair et al. 1999; Soranzo et al. 2000; Cheddadi et al. 2006). However on the basis of Scots pine mitochondrial DNA investigations, Pyhäjärvi et al. (2008) have supported lately the view that coniferous forests existed also outside the Mediterranean areas during the LGM, and these populations contributed to the subsequent colonization of the northern parts of Europe. According to Petit \& Hu (2008) genetic studies give a new dimension to palaeoecolgy, thus it is able to answer questions concerning the dynamics and biodiversity of palaeopopulations in more detail.

\section{Final remarks}

We have tried to outline above the advances in pollen analysis - the main palaeoecological method - in the last 
decade. Undoubtedly, it has made a great progress in the development of methods and their use for more precise interpretation of fossil data. However, the remark by Huntley (1996) seems still to be true: "The potential of palaeoecology is still poorly understood and little exploited by many ecologists".

The parallel development of palaeoecology and ecology is especially important nowadays when the environment is rapidly changing under the influence of intensified anthropopression. Objective grounds for the development of palaeoecological modelling are given by databases of modern pollen analogues for main types of vegetation communities and pollen monitoring in the European scale, based on standardized methods with the use of Tauber traps (Hicks et al. 1996). In the last decade, theoretical models have been successfully tested on palynological data from the Quaternary fossil deposits with a near-annual resolution. With the increasing potential of computer technologies, there are prospects for improvement of interpretive tools and for giving to ecology more and more precise data concerning vegetation communities in the past and other environmental variables reconstructed on the basis of pollen and non-pollen microfossils.

\section{Acknowledgments}

We are grateful to Prof. Małgorzata Latałowa for helpful discussion and comments at the preliminary stage of work on this paper.

This study was partially supported by research funds for the years 2007-2010 under a research project N30409232/3590 of the Ministry of Science and Higher Education in Poland.

\section{References}

Autio J. \& Hicks S., 2004, Annual variation in pollen deposition and meteorological conditions on the fell Aakenustunturi in northen Finland: potential for using fossil pollen as a climate proxy, Grana 43: 31-47.

Behre K.-E., 1981, The interpretation of anthropogenic indicators in pollen diagrams, Pollen et Spores 23: $225-245$.

Berglund B. E., Gaillard M.-J., Björkman L. \& Persson T., 2007, Long-term changes in floristic diversity in southern Sweden: palynological richness, vegetation dynamics and land-use, Vegetation History \& Archaeobotany 17: 573-583.

Braak C. J. F. ter \& Šmilauer P., 2002, CANOCO Reference Manual and User's Guide to Canoco for Windows: Software for Canonical Community Ordination (version 4.5), Microcomputer Power, Ithaca, N. Y., USA.
Brauer A., Endres Ch., Günter Ch., Litt T., Stebich M. \& Negedank J. F. W., 1999, High resolution sediment and vegetation responses to Younger Dryas climate change in varved lake sediments from Meerfelder Maar, Germany, Quaternary Science Reviews 18: 321-329.

Broström A., 2002, Estimating source area of pollen and pollen productivity in the cultural landscapes of southern Sweden - developing a palynological tool for quantifying past plant cover, LUNDQUA Thesis 46, Lund University.

Broström A., Nielsen A. B., Gaillard M.-J., Hjelle K., Maier F., Binney H., Bunting J., Fyfe R., Meltsov V., Poska A., Räsänen S., Soepboer W., von Stedingk H., Suutari H. \& Sugita S., 2008, Pollen productivity estimates of key European plant taxa for quantitative reconstruction of past vegetation: a review, Vegetation History and Archaeobotany 17: 461-478.

Brun C., Dessaint F., Richard H. \& Bretagnolle F., 2007, Arable-weed flora and its pollen representation: A case study from the eastern part of France, Review of Palaeobotany and Palynology 146: 29-50.

Bunting M. J., 2003, Pollen-based reconstruction of cultural landscapes: an investigation of pollen source area for non-arboreal taxa, Review of Palaeobotany and Palynology 125: 285-298.

Bunting M. J., Gaillard M. J, Sugita S., Middleton R., Broström A., 2004, Vegetation structure and pollen source area, The Holocene 14, 5: 651-660.

Cheddadi R., Mamakowa K., Guiot J., de Beaulieu J.-L., Reille M., Andrieu V., Granoszewski W. \& Peyron O., 1998, Was the climate of the Eemian stable? A quantitative climate reconstruction from seven European pollen records, Palaeogeography, Palaeoclimatology, Palaeoecology 143: 73-85.

Cheddadi R., Vendramin G. G., Litt T., Fraçois L., Kageyama M., Lorentz S., Laurent J. M., de Beulieu J.-L., Sadori L., Jost A. \& Lunt D., 2006, Imprints of glacial refugia in the modern genetic diversity of Pinus sylvestris, Glob. Ecol. Biogeogr. 15: 271-282.

Dahl A., \& Strandhede S.-O., 1996, Predicting the intensity of the birch pollen season, Aerobiologia 12: 97-106.

Davis M. B., 2000, Palynology after Y2K - understanding the source area of pollen in sediments, Ann. Rev. of Earth and Planetary Sci. 28: 1-18.

Desprat S., Goñi M. F. S. \& Loutre M.-F., 2003, Revealing climatic variability of the last three millennia in northwestern Iberia using pollen influx data, Earth and Planetary Science Letters 213: 63-78.

Emanuelson U., Greig J., Björkman L., Makohonienko M. \& van Leeuwen J., 1998, The selection of modern analogues of former land uses, [in:] M.-J.Gaillard, B. E. Berglund (eds.), Quantification of land surfaces cleared of forests during the Holocene - Modern pollen/vegetation/landscape relationships as an aid to the 
interpretation of fossil pollen data, Paläoklimaforschung Palaeoclimate Research vol. 27, Special issue: ESF Project "European Palaeoclimate and Man" 18, Gustav Fischer Verlag: 135-140.

Emberlin J., Mullins J., Cordon J., Millington W., Brooke M., Savage M., \& Jones S., 1997, The trend to earlier birch pollen season in the UK, a biotic response to change in weather conditions? Grana 36: 29-33.

Filbrandt-Czaja A., Noryśkiewicz A. M., Noryśkiewicz B. \& Pidek I. A., 2003, Variation of tree pollen influx values in several forested regions of Poland, [in:] XVI INQUA Congress - Abstracts, Reno, Nevada, USA, July 23-30, 2003: 211.

Filbrandt-Czaja A. \& Piernik A., 2006, The quantitative estimation of human impact on the landscape changes based on palynological and numerical analyses, Ecological Questions 7: 47-56.

Gaillard M.-J., Birks H. J. B., Emanuelsson U., Karlsson S., Lagerås P. \& Olausson D., 1994, Application of modern pollen/land-use relationships to the interpretation of pollen diagrams - reconstruction of land-use history in south Sweden, 3000-0 B.P., Review of Palaeobotany and Palynology 82: 47-73.

Gaillard M.-J., Sugita S., Bunting M. J., Middleton R., Broström A., Caseldine Ch., Giesecke T., Hellman S. E. V., Hicks S., Hjelle K., Langdon C., Nielsen A.-B., Poska A., von Stedingk H., Veski S. \& POLLANDCAL members, 2008, The use of modelling and simulation approach in reconstructing past landscapes from fossil pollen data: a review and results from the POLLANDCAL network, Vegetation History and Archaeobotany 17: 419-443.

Gerasimidis A., Panajotidis S. \& Athanasiadis N., 2008, Five decades of rapid forest spread in the Pieria Mountains (N. Greece) reconstruction by means of high-resolution pollen analysis and aerial photographs, Vegetation History and Archaeobotany 17: 639-652.

Gioulekas D., Balafoutis Ch., Damialis A., Papakosta D., Giolekas G., Patakas D., 2004, Fifteen years' record of airborne allergenic pollen and meteorological parameters in Thessaloniki, Greece, Journal of Biometeorolology 48: 128-136.

Goslar T., Bałaga K., Arnold M., Tisnerat N., Starnowska E., Kuźniarski M., Chróst L., Walanus A. \& Więckowski K., 1999, Climate-related variations in the composition of the Late-Glacial and Early Holocene sediments of Lake Perespilno (eastern Poland), Quaternary Science Reviews 18: 899-911.

Hellman S. E. V., Gaillard M.-J., Broström A. \& Sugita S., 2007 , Effect of the sampling design and selection of parameter values on pollen-based quantitative reconstructions of regional vegetation: a case study in southern Sweden using the REVEALS model, Vegetation History and Archaeobotany 17: 445-459.
Hicks S., 2001, The use of annual arboreal pollen deposition values for delimiting tree-lines in the landscape and exploring models of pollen dispersal, Review of Palaeobotany and Palynology 117: 1-29.

Hicks S., 2007, Surface samples and Trapping, [in:] S. A. Elias (ed.), Encyclopedia of Quaternary Science, vol. 3, Elsevier, Amsterdam: 2529-2535.

Hicks S. \& Hyvärinen V. P., 1987, Sampling modern pollen deposition by means of 'Tauber traps': some considerations, Pollen et Spores 28: 219-242.

Hicks S. \& Sunnari A., 2005, Adding precision to the spatial factor of vegetation reconstructed from pollen assemblages, Plant Biosysytems 139, 2: 127-134.

Hicks S., Ammann B., Latalowa M., Pardoe H. \& Tinsley H., 1996, European Pollen Monitoring Programme, Project Description and Guidelines, Oulu Univ. Press, Oulu, Finland.

Hicks S., Tinsley H., Pardoe H. \& Cundill P., 1999, European Pollen Monitoring Programme, Supplement to the Guidelines, Oulu Univ. Press, Oulu, Finland.

Hjelle K. L., 1998, Relationships between modern pollen deposition and the vegetation in mown and grazed communities in western Norway and their application to the interpretation of past cultural activity. Dept. of Botany, University of Bergen, Norway.

Hrynowiecka-Czmielewska A., Filbrandt-Czaja A. \& Nienartowicz A., 2007, Modern pollen-vegetation relationship in the Tuchola Forest, Ecological Questions 8: 47-71.

Huntley B., 1996, Quaternary palaeoecology and ecology, Quaternary Science Reviews 15: 591-606.

Jacobson G. L. \& Grimm E. C., 1986, A numerical analysis of Holocene Forest and prairie vegetation in central Minnesota, Ecology 67: 958-966.

Jankovská V. \& Komárek J., 2000, Indicative value of Pediastrum and other coccal green algae in palaeoecology, Folia Geobotanica 35: 59-82.

Kasprzyk I., Uruska A., Szczepanek K., Latałowa M., Gawel J., Harmata K., Myszkowska D., Stach A. \& Stępalska D., 2004, Regional differentiation in the dynamics of the pollen seasons of Alnus, Corylus and Fraxinus in Poland (preliminary results), Aerobiologia 20: 141-151.

Kaszewski B. M., Pidek I. A., Piotrowska K. \& WeryszkoChmielewska E., 2008, Annual pollen sums of Alnus in Lublin and Roztocze in the years 2001-2007 against selected meteorological parameters, Acta Agrobotanica (in press).

Latałowa M., 2003a, Podstawy interpretacji wyników analizy pyłkowej osadów czwartorzędowych [Interpretation of the rulet of the Quaternary sediments pollen analysis - Basic rules], [in:] S. Dybova-Jachowicz, A. Sadowska (eds.), Palinologia [Palynology], Wyd. Inst. Bot. PAN, Kraków: 224-233. 
Latałowa M., 2003b, Mikrofosylia pozapyłkowe w osadach dennych Zalewu Szczecińskiego [Non-pollen microfossils in the bottom sediments of the Szczecin Lagoon], Prace Komisji Paleogeografii Czwartorzędu Polskiej Akademii Umiejętności 1: 125-128.

Latałowa M., Miętus M. \& Uruska A., 2002, Seasonal variations in the atmospheric Betula pollen count in Gdańsk (southern Baltic cost) in relation to meteorological parameters, Aerobiologia 18: 33-43.

Latałowa M. \& van der Knaap W. O., 2006, Late Quaternary expansion of Norway spruce Picea abies (L.) Karst. in Europe according to pollen data, Quaternary Science Reviews 25, issue 21-22: 2780-2805.

Levetin E., Rogers C. \& Hall S., 2000, Comparison of pollen sampling with a Burkard Spore Trap and Tauber Trap in a warm temperate climate, Grana 39: 294 302.

Litt T., Brauer A., Goslar T., Merkt J., Bałaga K., Müller H., Ralska-Jasiewiczowa M., Stebich M. \& Negedank J. F. W., 2001, Correlation and synchronisation of Lateglacial continental sequences in northern central Europe based on annually laminated lacustrine sediments, Quaternary Science Reviews 20: 1233-1249.

Makohonienko M., Gaillard M.-J. \& Tobolski K., 1998, Modern pollen/land-use relationships in ancient cultural landscapes of North-western Poland, with emphasis on mowing, grazing and crop cultivation, [in:] Quatification of land pollen/vegetation/ landscape relationships as an aid to the interpretation of fossil pollen data. Paläoklimaforschung, 27, Special Issue: ESF Project "European Palaeoclimate and Man" 18 (ed. B. Frenzel), Gustav Fischer Verlag: 85-101.

Mazier F., Broström A., Gaillard M.-J., Sugita S., Vittoz P. \& Buttler A., 2008, Pollen productivity estimates and relevant source area of pollen for selected plant taxa in a pasture woodland landscape of the Jura Mountains (Switzerland), Vegetation History and Archaeobotany 17: 479-495.

Myczkowski S., 1961, Zespoły leśne rezerwatu cisowego Wierzchlas [Forest associations of the yew reserve of Wierzchlas], Ochrona Przyrody 27: 91-108.

Nalepka D., 2005, Late Glacial and Holocene palaeoecological conditions and changes of vegetation cover under early farming activity in the South Kujawy region (Central Poland), Acta Palaeobotanica, Suppl. 6: 3-90.

Noryśkiewicz A. M., 2001, mscr., Historia cisa we Wierzchlesie na tle postglacjalnej historii roślinności [The history of yew in Wierzchlas on the background of postglacial history of vegetation], UAM, Poznań.

Noryśkiewicz A. M., 2006, Historia cisa w okolicy Wierzchlasu w świetle analizy pyłkowej [The history of yew in the region of Wierzchlas in the light of pollen analysis], Wyd. UMK, Toruń.
Noryśkiewicz B., 2005, Seven years of annual pollen deposition in the Brodnica Lake District (N Poland) - relations to vegetation and climate, [in:] Filipova-Marinova M., Hicks S. (eds.) Pollen Monitoring Programme, $5^{\text {th }}$ International Meeting, Varna, Bulgaria. Volume of Abstracts: 29.

Obidowicz A., Ralska-Jasiewiczowa M., Kupryjanowicz M., Szczepanek K., Latałowa M. \& Nalepka D., 2004, Picea abies (L.) H. Karst. - Spruce, [in:] M. Ralska-Jasiewiczowa, M. Latałowa, K. Wasylikowa, K. Tobolski, E. Madeyska, Wright H. E. Jr., Ch. Turner (eds.), 2004, Late Glacial and Holocene history of vegetation in Poland based on isopollen maps, W. Szafer Institute of Botany, Polish Academy of Sciences, Kraków: 147-157.

Petit R. J., Aguinagalde I., de Beaulieu J.-L., Bittkau C., Brewer S., Cheddadi R., Ennos R., Fineschi S., Grivet D., Lascoux M., Mohanty A., Müller-Starck G. M., Demesure-Musch B., Palmé A., Martin J. P., Rendell S. \& Vendramin G. G., 2003, Glacial refugia: Hotspots but not melting pots of genetic diversity, Science 300: 1563-1565.

Petit R. J. \& Hu F. S., 2008, Palaeoecology meets genetics: deciphering past vegetational dynamics, Terra Nostra 2008/2, $12^{\text {th }}$ International Palynological Congress. 8th International Organisation of Palaeobotany Conference. August 30-September 5, 2008 in Bonn, Germany, Abstract Vol.: 220.

Peyron O., Guiot J., Cheddadi R., Tarasov P., Reille M., de Beulieau J.-L., Bottema S. \& Andrieu V., 1998, Climatic Reconstruction in Europe for 18000 YR B.P. from Pollen Data, Quaternary Research 49, 2: 183-196.

Pidek I. A., 2007, Nine-year record of Alnus pollen deposition in the Roztocze region (SE Poland) with relation to vegetation data, Acta Agrobotanica 60, 2: 57-64.

Pidek I. A. \& Kaszewski B. M., 2005, Zmienność koncentracji pyłku buka zwyczajnego (Fagus sylvatica L.) w lasach Roztocza na tle czynników meteorologicznych [Variation in beech (Fagus sylvatica L.) pollen concentration in the background of meteorological factors], Annales UMCS, sec. B, vol. LX, 10: 147-163.

Pidek I. A., Weryszko-Chmielewska E. \& Piotrowska K., 2006, Comparison of pollen concentration of selected tree taxa in Lublin and in the Roztocze region (SE Poland) - the results of three monitoring methods, Acta Agrobotanica 59, 1: 355-364.

Pidek I. A., Zimny M., Noryśkiewicz B., Święta-Musznicka J., Filbrandt-Czaja A., Noryśkiewicz A. M. \& Kaszewski B. M., 2008a, Annual pollen accumulation rates (PARs) of Picea and Pinus along SE-NW transect in Poland in relation to vegetation data and summer air temperatures, Terra Nostra 2008/2, $12^{\text {th }}$ International Palynological Congress, 8th International Organisation of Palaeobotany Conference, August 30-September 5, 2008 in Bonn, Germany, Abstract Vol.: 223. 
Pidek I. A., Weryszko-Chmielewska E., Piotrowska K., 2008b, Czy istnieje dwuletni rytm obfitego pylenia brzozy i olszy? [Does the biennual rhythm of abundant birch and alder flowering exist?], Allergologia. Immunologia 5, 2: 61-65.

Poska A., Pidek I. A., 2007, Estimating spatial scale of pollen dispersal in the semi-cultural landscape of the Roztocze region (SE Poland), [in:] L. Kalnina, E. Luksevics (eds.), Volume of Abstracts, Pollen Monitoring Programme, $6^{\text {th }}$ International Meeting, 3-9 June 2007, Jurmala, Latvia, University of Latvia. Rīga: 69-73.

Pyhäjärvi T., Salmela M. J. \& Savolainen O., 2007, Colonization routes of Pinus sylvestris inferred from distribution of mitochondrial DNA variation, Tree Genetics \& Genomes 4: 247-254, Springer, DOI 10.1007/ s11295-007-0105-1.

Ralska-Jasiewiczowa M., Goslar T., Madeyska T. \& Starkel L. (eds.), 1998, Lake Gościąż, Central Poland, A Monographic Study, Part I, W. Szafer Institute of Botany, Kraków.

Ralska-Jasiewiczowa M., Latałowa M., Wasylikowa K., Tobolski K., Madeyska E., Wright H. E. Jr. \& Turner Ch. (eds.), 2004, Late Glacial and Holocene history of vegetation in Poland based on isopollen maps, W. Szafer Institute of Botany, Polish Academy of Sciences, Kraków: 11-444.

Ranta H., Sokol C. \& Hicks S., 2007, Comparison of timeseries measurements between a volumetric air sampler and a Tauber pollen trap in the northern tree-line area of Fennoscandia, Presentation at the 6th International Meeting of the Pollen Monitoring Programme, 3-9 June 2007, Jurmala, Latvia: 73-74.

Räsänen S., 2001, Tracing and interpreting fine-scale human impact in northern Fennoscandia with the aid of modern pollen analogue, Vegetation History and Archaeobotany 10: 211-218.

Räsänen S., Suutari H. \& Nielsen A. B., 2007a, A step further towards quantitative reconstruction of past vegetation in Fennoscandian boreal forests: pollen productivity estimates for six dominant taxa, Review of Palaeobotany and Palynology 146, 1-4: 208-220.

Räsänen S., Froyd C. \& Goslar T., 2007b, The impact of tourism and reindeer herding on forest vegetation at Saariselkä, Finnish Lapland: a pollen analytical study of a high resolution peat profile, The Holocene 17, 4: 447-456.

Sinclair W. T., Morman J. D. \& Ennos R. A., 1999, The postglacial history of Scots pine (Pinus sylvestris L.) in Western Europe: evidence from mitochondrial DNA variation. Mollecular Ecology 8: 83-88.

Sjögren P., van der Knaap W. O., Huusko A. \& van Leeuwen J. F. N., 2008, Pollen productivity, dispersal, and correction factors for major tree taxa in the Swiss Alps based on pollen-trap results, Review of Palaeobotany and Palynology DOI: 10.1016/j.revpalbo.2008.05.003

Soranzo N., Alia R., Provan J. \& Powell W., 2000, Patterns of variation at a mitochondrial sequence-tagged-site locus provides new insights into the post glacial history of European Pinus sylvestris populations, Mollecular Ecology 9: 1205-1211.

Spieksma F. Th. M., Corden J. M., Detandt M., Millington W. M., Nikkels H., Nolard N., Schoenmakers C. H. H., Wachter R., de Weger L. A., Willems R. \& Emberlin J., 2003, Quantitative trends in annual totals of five common airborne pollen types (Betula, Quercus, Poaceae, Urtica and Artemisia), at five pollen-monitoring stations in western Europe, Aerobiologia 19: 171-184.

Sugita S., 1994, Pollen representation of vegetation in Quaternary sediments: theory and method in patchy vegetation, J. Ecol. 82: 881-897.

Sugita S., 1998, Modelling pollen representation of vegetation, [in:] M.-J.Gaillard, B. E. Berglund, B. Frenzel, U. Huckriede (eds.), Quantification of land surfaces cleared of forests during the Holocene, Paläoklimaforschung/ Palaeoclimate Research 27, Stuttgart: Gustav Fischer Verlag: 1-16.

Sugita S., 2007a, Theory of quantitative reconstruction of vegetation, I. Pollen from large sites REVEALS regional vegetation, Holocene 17: 229-241.

Sugita S., 2007b, Theory of quantitative reconstruction of vegetation, II. All you need is LOVE, The Holocene 17: 243-257.

Święta-Musznicka J. \& Zimny M., 2007, Modern annual pollen deposition in the Kashubian Lakeland (N Poland) against aerobiological data from Gdańsk, [in:] L. Kalnina, E. Luksevics (eds.), Volume of Abstracts, Pollen Monitoring Programme, $6^{\text {th }}$ International Meeting, 3-9 June 2007, Jurmala, Latvia, University of Latvia. Rīga: $81-82$.

Tarasov P. E., Guiot J., Cheddadi R., Andreev A. A., Bezusko L. G., Blyakharchuk T. A., Dorofeyuk N. I., Filimonova L. V., Volkova V. S. \& Zernitskya V. P., 1999, Climte in northern Eurasia 6000 years ago reconstructed from pollen data, Earth and Planetary Science Letters 171: 635-645.

Tipper J. C., 1979, Rarefaction and rarefiction - the use and abuse of a method in palaeoecology, Paleobiology 5: 423-34.

Tonkov S., Hicks S., Bozilova E. \& Atanassova J., 2001, Pollen monitoring in the central Rila Mountains, Southwestern Bulgaria: comparisons between pollen traps and surface samples for the period 1993-1999, Review of Palaeobotany and Palynology 117: 167-182.

van der Knaap W. O., van Leeuven J. F. N. \& Ammann B., 2001, Seven years of annual pollen influx at the forest limit in the Swiss Alps studied by pollen traps in rela- 
tion to vegetation and climate, Review of Palaeobotany and Palynology 117: 31-52.

van der Knaap W. O. \& van Leeuwen J. F. N., 2003, Climate-pollen relationships AD 1901-1996 in two small mires near the forest limit in the northern and central Swiss Alps, The Holocene 13, 6: 809-828.

van Geel B., 2006, Fossil ascomycetes in Quaternary deposits, Nova Hedvigia, Stuttgart, 82, 3-4: 313-329.

van Geel B., Buurman J., Brinkkemper O., Schelvis J., Aptroot A., van Reznen G. \& Hakbijl T., 2003, Environmental reconstruction of a Roman Period Settlement site in Uitgeest (The Netherlands), with special reference to coprophilous fungi, Journal of Archaeological Science 30: 873-883.

van Leeuwen J., 2007, Spores of fungi on dung in Swiss Alpine pollen traps and in sediments from the Alps, Bhutan, and the Azores, [in:] L. Kalnina, E. Luksevics (eds.), Volume of Abstracts, Pollen Monitoring Programme, $6^{\text {th }}$ International Meeting, 3-9 June 2007, Jurmala, Latvia, University of Latvia, Rīga: 50.

Walanus A. \& Nalepka D., 1999, POLPAL. Program for counting pollen grains, diagrams plotting and numerical analysis, Acta Paleobotanica, Suppl. 2: 659-661.

Whitmore J., Gajewski K., Sawada M., Williams J. W., Shuman B., Bartlein P. J., Minckley T., Viau A. E., Webb III T., Shafer S., Anderson P. \& Brubaker L., 2005, Modern pollen data from North America and Greenland for multi-scale paleoenvironmental applications, Quaternary Science Reviews 24: 1828-1848.

Wilmshurst J. M. \& McGlone M. S., 2005, Origin of pollen and spores in surface lake sediments: comparison of modern palynomorph assemblages in moss cushions, surface soils and surface lake sediments, Review of Palaeobotany and Palynology 136: 1-15. 